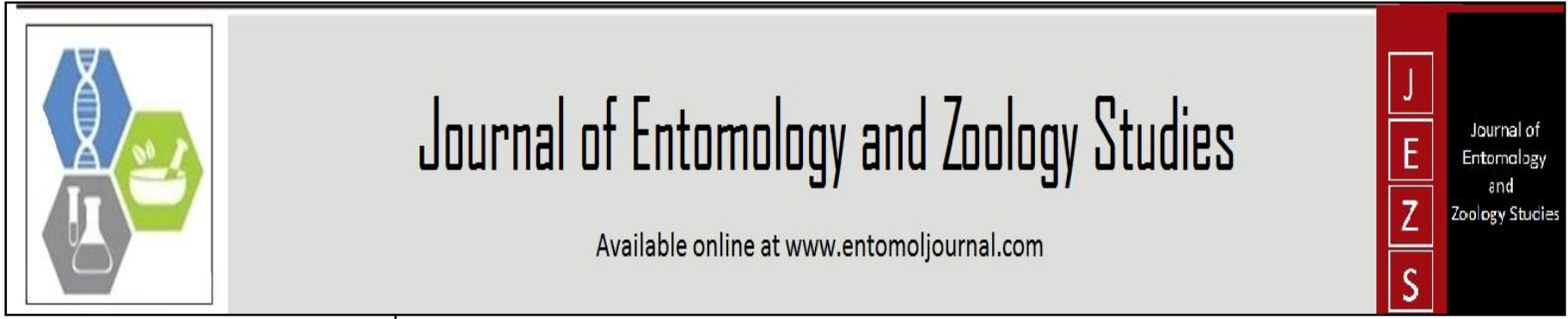

E-ISSN: 2320-7078

P-ISSN: 2349-6800

JEZS 2020; 8(1): 69-72

(C) 2020 JEZS

Received: 06-11-2019

Accepted: 10-12-2019

Dhimmar H

Post Graduate Institute of

Fisheries Education and Research,

Kamdhenu University,

Gandhinagar, Gujrat, India

Vala SR

Post Graduate Institute of

Fisheries Education and Research,

Kamdhenu University,

Gandhinagar, Gujrat, India

\section{Lende SR}

Post Graduate Institute of

Fisheries Education and Research,

Kamdhenu University,

Gandhinagar, Gujrat, India

\section{Jora K}

Post Graduate Institute of

Fisheries Education and Research,

Kamdhenu University,

Gandhinagar, Gujrat, India

\section{Vagh SN}

Post Graduate Institute of

Fisheries Education and Research,

Kamdhenu University,

Gandhinagar, Gujrat, India

Mevada J

Post Graduate Institute of

Fisheries Education and Research,

Kamdhenu University,

Gandhinagar, Gujrat, India

Fofandi DC

Post Graduate Institute of

Fisheries Education and Research,

Kamdhenu University,

Gandhinagar, Gujrat, India

\section{Dhimmer S.}

Post Graduate Institute of

Fisheries Education and Research,

Kamdhenu University,

Gandhinagar, Gujrat, India

Corresponding Author:

Dhimmar $\mathbf{H}$

Post Graduate Institute of

Fisheries Education and Research,

Kamdhenu University,

Gandhinagar, Gujrat, India

\section{Quality attributes and shelf life assessment of black pomfret (Formio niger) steaks treated with salts of organic acids}

\author{
Dhimmar H, Vala SR, Lende SR, Jora K, Vagh SN, Mevada J, Fofandi \\ DC and Dhimmer $S$
}

\section{Abstract}

The main objective of this study was to assess effects of food grade sodium acetate and water dip as control treatments on the chemical, physical and sensorial quality attributes of decapitated black pomfret (Formio niger) during chilled storage at $4{ }^{\circ} \mathrm{C}$ for 7 days. Results indicated that control fish samples have been shown to lose texture, and show a gradual deterioration in quality attributes with chilled storage. The rates of these deteriorations are increased as the time of storage progressed. On the other hand, Sodium acetate treated fish samples exhibit higher moisture retention, tenderness, and bound water at any given time of chilled storage as compared with control samples. The present data also demonstrate lower values of drip loss, TVB-N and TMAN, are recorded in sodium acetate-treated samples. Analysis indicated that chemical, physical and sensorial quality advantages have been resulted from soaking black pomfret (Formio niger) in chilled temperature at 2.5\% Sodium acetate solution for 5 minutes prior to freezing. Organic acid treatment can be an alternative way to improve the quality of decapitated black pomfret (Formio niger) during chilled storage. We can conclude that, sodium acetate dip treatment is for the maintenance of the functional properties of the seafood proteins which helps the preservation of the muscle integrity.

Keywords: Black pomfret steaks, sodium acetate, organic salt, TVB-N, TMA-N

\section{Introduction}

Fish is a vital source of food for people. It is man's most important single source of high- quality protein, providing $\sim 16 \%$ of the animal protein consumed by the world's population, according to the Food and Agriculture Organisation (FAO) of the United Nations (1997) [7]. However, it is highly susceptible to both microbiological and chemical deterioration, due to its high-water activity, neutral $\mathrm{pH}$, relatively large quantities of free amino acids, and presence of autolytic enzymes (Jeyasekaran et al., 2006) ${ }^{[9]}$.

Black pomfret (Formio niger) is a species of carangid native to reefs of the Indian Ocean and the western Pacific Ocean, where it is found at depths from 15 to $105 \mathrm{~m}$ ( 49 to $344 \mathrm{ft}$ ), though it is rarely found deeper than $40 \mathrm{~m}(130 \mathrm{ft})$. This species grows to $75 \mathrm{~cm}(30 \mathrm{in})$ in total length and is very important to local commercial fisheries. This species is the only known member of its genus (Froese et al. 2013) ${ }^{[6]}$. Texture is considered to be one of the most important quality attributes of fish and meat. It contributes to consumer acceptance and therefore marketability of the final product (Cheret, Delbarre- Ladrat, Lamballerie- Anton, \& Verrez- Bagnis, 2007) ${ }^{[4]}$. Fish texture is mainly dependent upon its fat and collagen content; however, muscles softening can occur as a result of myofibrillar protein degradation due to microbiological and autolysis processes initiated at fish death (Li et al., 2012) ${ }^{[14]}$.

Sodium acetate is found to be effective in preventing microbial growth and improving shelflife under different storage conditions (Kim et al., 1995) ${ }^{[11]}$. Sodium acetate is an approved (USFDA) flavouring and $\mathrm{pH}$ control agent. 2\% NaAc (sodium acetate) was effective in controlling growth of natural micro flora on catfish fillets Zhuang et al. (1996) ${ }^{[25]}$. Black pomfret (Formio niger) is a species with high commercial value and much appreciated by world over consumers. It is sold as either whole fresh fish or in fillet form. Additionally, vacuum packaged fish are being consumed. 


\section{Materials and Method}

Fresh Black Pomfret (Formio niger) was taken from Veraval (Gujarat) fish market. Than Preserve it in ice box and immediately transfer to laboratory. Wash material several times by freshwater and degutted and make steaks of fish. Weigh all steaks using electric weighing machine (Docbel Braun). Divide all steaks into two division by weigh for two treatments. Took water in one plastic tray and $2.5 \%$ Sodium acetate solution in another plastic tray. Half part of steaks dip into water and another half part of steaks dip into $2.5 \%$ Sodium acetate solution for 10 to 15 minutes. After onwards both types of sample was allow to dry partially at room temperature for 20 minutes. Then steaks was pack in polythene pouch with use of sealing machine (QS $200 \mathrm{FE}$ ). Both sample was labelled with A1 and A2. Where, A1 was Non-treated fish steaks (steaks dip in water) and A2 was treated with $2.5 \%$ sodium acetate. A1 and A2 sample was stored in chill storage at $4{ }^{\circ} \mathrm{C}$.

Analyse sample by Measure Moisture, TVBN, TMA, pH, Colour (L, a, b), Appearance, Colour, Odour, Overall Acceptability of each treatment. Black pomfret steaks were sampled for examination at storage days 3, 5, 7 .

\section{Analysis method \\ Total volatile basic nitrogen (Tvb-N) analysis}

Total Volatile Basic Nitrogen (TVB-N) was determined according to the method of Conway (1950) ${ }^{[3]}$. $1 \mathrm{ml}$ of $0.01 \mathrm{~N}$ Sulfuric Acid solution was added into inner ring (chamber) with the use of pipette. Then, $1 \mathrm{ml}$ of standard N/100 sulphuric acid was taken in the inner chamber of the diffusion unit. To the outer chamber $1 \mathrm{ml}$ of TCA extract was added and the glass lid applied with vacuum grease was covered over it, leaving a small space. Through this space $1 \mathrm{ml}$ of saturated potassium carbonate was added and the unit was sealed immediately with the glass lid, rotated slowly to mix the contents and kept undisturbed overnight. The amount of unreacted acid in the inner chamber was determined by titrating against standard N/100 sodium hydroxide using Tashiro's indictor (Kamalakanth, 2016) ${ }^{[10]}$. Similarly a blank was also run using $1 \mathrm{ml}$ of $20 \%$ TCA instead of sample extract. TVB-N was calculated and expressed as mg N2 100 $\mathrm{g}-1$ of the sample below.

TVB-N $\quad(\mathrm{Vb}-\mathrm{Vs}) \times 0.14 \times$ Volume of extract $\times 100$ $(\mathrm{mg} / 100 \mathrm{~g})=\quad$ Vol. of sample taken $\times$ Weight of sample

\section{Where}

$\mathrm{Vb}=$ Titrate volume of $0.01 \mathrm{~N} \mathrm{NaOH}$ for the blank $(\mathrm{ml})$ $\mathrm{Vs}=$ Titrate volume of $0.01 \mathrm{~N} \mathrm{NaOH}$ for the sample $(\mathrm{ml})$

\section{Trimethylamine nitrogen (Tma-N) analysis}

TMA was determined as trimethyl amine nitrogen (TMA-N) by the micro diffusion method (Conway, 1950) ${ }^{[3]} .1 \mathrm{ml}$ of standard N/100 sulphuric acid was added in the inner chamber of the diffusion unit. To the outer chamber $1 \mathrm{ml}$ of TCA extract was added followed by $1 \mathrm{ml}$ neutralized formaldehyde. This was kept for 3 min to ensure the binding of formaldehyde with all the primary and secondary amines and ammonia contained in the extract. To this, $1 \mathrm{ml}$ saturated potassium carbonate was added and the analysis was further carried out as explained in TVB-N determination (Kamalakanth, 2016) ${ }^{[10]}$. The only difference was the blank also run using $1 \mathrm{ml}$ of $20 \%$ TCA instead of sample extract.
TMA-N was calculated and expressed as mg N2100 g-1 of the sample.

TMA $(\mathrm{mg}$
$/ 100 \mathrm{~g})=\frac{(\mathrm{Vb}-\mathrm{Vs}) \times 0.14 \times \text { Volume of extract } \times 100}{\text { Vol. of sample taken } \times \text { Weight of sample }}$

\section{Where}

$\mathrm{Vb}=$ Titrate volume of $0.01 \mathrm{~N} \mathrm{NaOH}$ for the blank $(\mathrm{ml})$ $\mathrm{Vs}=$ Titrate volume of $0.01 \mathrm{~N} \mathrm{NaOH}$ for the sample $(\mathrm{ml})$

\section{Moisture analysis}

Moisture determination is one of the most important and most widely used measurements in the processing and testing of foods (Pomeranz et al., 1994) ${ }^{[21]}$. Black pomfret being perishable commodity contains $74.3 \%$ moisture content (P. Puwastien et al.) ${ }^{[20]}$.

Dry the empty dish and lid in the oven (IFB 30SRC2) at 105 ${ }^{\circ} \mathrm{C}$ for $3 \mathrm{~h}$ and transfer to desiccator to cool. Weigh the empty the dish and lid. Weigh about $10 \mathrm{~g}$ of sample to the dish. Spread the sample with spatula. Place the dish with sample in the oven. Dry for $3 \mathrm{~h}$ at $105^{\circ} \mathrm{C}$. After drying, transfer the dish with partially covered lid to the desiccator to cool. Reweigh the dish and its dried sample (AOAC, 1999).

Moisture $(\%)=\frac{(\mathrm{W} 1-\mathrm{W} 2) \times 100}{\mathrm{~W} 1}$

\section{Where}

$\mathrm{W} 1$ = weight $(\mathrm{g})$ of sample before drying

$\mathrm{W} 2$ = weight $(\mathrm{g})$ of sample after drying

\section{pH analysis}

The $\mathrm{pH}$ value was recorded using a $\mathrm{pH}$ testing paper.

\section{Colour analysis}

In industry, the colour of foods has generally been measured using $\mathrm{L}^{*} \mathrm{a} * \mathrm{~b} *$ or CIELab colour space, which is an international standard accepted by the Commission Internationale de l'Eclairage (CIE) in 1976 (Leon et al., 2006) ${ }^{[15]}$ In the CIE Lab system, L* denotes lightness component 0 to 100 scale from black to white; $\mathrm{a}^{*}$,(q) red or (y) green; and $\mathrm{b}^{*}$, (q) yellow or (y) blue (Schubring et al., 2003) ${ }^{[23]}$. Using whiteness meter (Konica Minolta Colorimeter CR-14) colour analysis had been done.

\section{Sensory analysis}

Sensory appraisal of raw fillets (Pastoriza et al., 1998) ${ }^{[22]}$ was done. The sensory appraisal was done by 4 panellists. The estimation was conducted for the appearance, colour, odour and overall acceptability of black pomfret raw material, marinated \& non-marinated product. Overall acceptability was calculated by adding the scores for all the attributes and dividing by total number of attributes (C. O. Mohan et al., 2010) ${ }^{[19]}$.

\section{Statistical analysis}

Differences between means were analyzed by one-way analysis of variance (ANOVA) followed by Tukey and Duncan tests. The results are presented as means $\pm \mathrm{SD}$. When a significant difference was detected between the groups $(p<$ $0.05)$, either the Tukey or Duncan multiple comparison test was applied to obtain the conservative differences with multiple comparison (Berna Kilinc et al., 2009) ${ }^{[12]}$. 
Result and Discussion

Changes in total volatile base nitrogen (Tvb-N) and Trimethylamine nitrogen (Tma-N)

Due to microbial activity degradation of proteins and nonproteins compounds start and TVB-N produced (Connell, 1975) [5]. In freshly caught fish TVB-N concentration is normally between 5 and $20 \mathrm{mg} \mathrm{N} 100 \mathrm{~g}^{-1}$ (Huss, 1988) ${ }^{[8]}$. A level of $35-40 \mathrm{mg} \%$ is usually regarded as the limit of acceptability (S. Manju et al., 2007) ${ }^{[18]}$. The TVB-N value of raw fish was $12 \mathrm{mg} \mathrm{N} 100 \mathrm{~g}-1$ at the beginning. A1 and A2 value 41 and 32 at the end of the storage period (7 days), respectively (Table 1).

Values of TVB-N found raise with storage period in treated and non-treated steak. Non-treated steak was more content of TVB-N compared to treated steak TVB-N value. TVB-N value low in treated samples were due to either a decreased capacity of bacteria for oxidative deamination of non-protein nitrogen compounds or a reduced bacterial population or both (Banks, Nickelson \& Finne, 1980) ${ }^{[2]}$. The TVB-N contents of potassium sorbate treated samples were slightly lower than sodium acetate treated samples for both species Parastromateus niger and Etroplus suratensis. This might be attributed to the greater inhibition of gram-ve bacteria by potassium sorbate than by sodium acetate (S. Manju et al., 2007) ${ }^{[18]}$. Kim and Hearnsberger (1994) and Kim et al. (1995) $[13,11]$ observed that sodium acetate restricted aerobic gram-ve spoilage bacteria.

The beginning of TMA-N value was $2.1 \mathrm{mg} \mathrm{N} / 100 \mathrm{~g}$. Sodium acetate treated sample in TMA-N value low within 7 days, whereas for the non-treated samples in TMA-N showed a progressive increase. The Sodium acetate effect in fish steak inhibiting the increased production of TMA-N. However, the increase was higher for not-treated samples compared to treated samples. The acceptability limit of TMA-N (15 mg $\mathrm{N} 2 / 100 \mathrm{~g}$ ) according to S. Manju et al. (2007) ${ }^{[18]}$. That was exceeded on 7 day for non-treated sample, but limit not exceeded for treated steak in 7 days.

Table 1: TVB-N changes (mg TVB-N/100 g) and TMA-N changes (mg TMA-N/100 g) of black pomfret steaks stored At $4{ }^{\circ} \mathrm{C}$

\begin{tabular}{|c|c|c|c|c|c|c|c|}
\hline \multirow{2}{*}{$\begin{array}{c}\text { Storage (days) } \\
\text { Components }\end{array}$} & \multirow{2}{*}{\begin{tabular}{|c|} 
Zero days \\
Raw
\end{tabular}} & \multicolumn{2}{|c|}{3 days } & \multicolumn{2}{|c|}{5 day } & \multicolumn{2}{|c|}{7 days } \\
\hline & & A1 & A2 & A1 & A2 & A1 & A2 \\
\hline TVB-N (mg N/100g) & 12 & 24 & 22 & 31 & 28 & 41 & 32 \\
\hline TMA (mg N/100g) & 2.1 & 8 & 7 & 14 & 11 & 19 & 14 \\
\hline
\end{tabular}

A1: Non-treated fish steak, A2: Fish steak Treated with 2.5\% sodium acetate.

\section{Changes in moisture}

Comparatively there was not much difference found between treated and non-treated fish steak shown in Table 2. Moisture content in black pomfret fish steaks was $82.26 \%$ in the beginning and at end of the $7^{\text {th }}$ day moisture content was $75 \%$ in non-treated, $75.69 \%$ in treated fish steaks. It indicate that Sodium acetate treated fish steak was slightly more moisture content.

Table 2: Moisture content in Black Pomfret Steaks Stored At $4{ }^{\circ} \mathrm{C}$

\begin{tabular}{|c|c|c|c|c|}
\hline Storage day & Raw Material & 3rd day & 5th day & 7th day \\
\hline A1 & \multirow{2}{*}{82.26} & 81.34 & 79.21 & 75.00 \\
\cline { 1 - 4 } \cline { 3 - 5 } A2 & & 82.16 & 79.83 & 75.69 \\
\hline
\end{tabular}

A1: Non-treated fish steak, A2: Fish steak Treated with $2.5 \%$ sodium acetate.

\section{Changes in $\mathbf{p H}$}

The changes in $\mathrm{pH}$ for Black pomfret steaks treated with and without sodium salts are shown in Table 3. The $\mathrm{pH}$ of the Sodium treated and non- treated fish steak was $7.1 \pm 0.21$ measured where both had same $\mathrm{pH}$ value. On day 7 , this value was determined as in non-treated sample was $5.25 \pm 0.20$ and in treated sample was $5.85 \pm 0.19$. Due to the effects of sodium salts less $\mathrm{pH}$ decreased in treated samples comparatively non-treated steak more $\mathrm{pH}$ decreased. (Berna Kilinc at. al., 2009) ${ }^{[12]}$ revealed that $\mathrm{pH}$ value increased with use of Sodium acetate treatment packed with polyvinylidene film in raimbo trout. Usually limit of acceptability is $6.8-7.0$ (Ludorff and Meyer, 1973) ${ }^{[16]}$.

Table 3: $\mathrm{pH}$ content in black pomfret steaks stored at $4{ }^{\circ} \mathrm{C}$

\begin{tabular}{|c|c|c|c|c|}
\hline Storage day & Zero day & $\mathbf{3}^{\text {rd }}$ day & $\mathbf{5}^{\text {th }}$ day & $\mathbf{7}^{\text {th }}$ day \\
\hline A1 & $7.1 \pm 0.21$ & $6.6 \pm 0.14$ & $5.7 \pm 0.14$ & $5.25 \pm 0.20$ \\
\hline A2 & $7.1 \pm 0.21$ & $6.2 \pm 0.21$ & $5.9 \pm 0.18$ & $5.85 \pm 0.19$ \\
\hline
\end{tabular}

A1: Non-treated fish steak, A2: Fish steak Treated with $2.5 \%$ sodium acetate.

\section{Changes in colour}

Color measurements of Sodium acetate treated and nontreated black pomfret are shown in Tables 4 . The $\mathrm{L}^{*}$ (Lightness), a, b value of Sodium acetate treated and nontreated were determined as 42.9, 24.1, 16.5 at the before the storage period. On $7^{\text {th }}$ day, $\mathrm{L}^{*}$ value changed to 29.9 and 27.4 for Sodium acetate treated and non-treated, respectively. The $\mathrm{a}^{*}$ (+ red or - green) value changed to 7.6 and 8.2 for Sodium acetate treated and non-treated, respectively. The $b^{*}$ (+ yellow or - blue) value changed to 26.5 and 25.4 for Sodium acetate treated and non-treated, respectively.

Table 4: Colour analyses in black pomfret steaks stored at $4{ }^{\circ} \mathrm{C}$

\begin{tabular}{|c|c|c|c|c|c|c|c|c|c|c|c|c|}
\hline & \multicolumn{3}{|c|}{ RAW } & \multicolumn{3}{c|}{ DAY 3 } & \multicolumn{3}{c|}{ DAY 5 } & \multicolumn{3}{c|}{ DAY 7 } \\
\hline & L & a & b & L & a & b & L & a & b & L & a & B \\
\hline A1 & \multirow{2}{*}{42.9} & \multirow{2}{*}{24.1} & \multirow{2}{*}{16.5} & 35.8 & 14.5 & 20.5 & 29.4 & 8.4 & 19.2 & 27.4 & 8.2 & 25.4 \\
\cline { 5 - 11 } A2 & & & & 39.7 & 16.4 & 19.2 & 30.2 & 7.4 & 24.2 & 29.9 & 7.6 & 26.5 \\
\hline
\end{tabular}

A1: Non-treated fish steak, A2: Fish steak Treated with $2.5 \%$ sodium acetate.

\section{Changes in sensory evaluation}

The overall sensory assessment of Black pomfret fish steaks are given in Table 5. On the beginning day, black pomfret fish had different sensory component appearance, colour, odour which was changed with storage period. Sodium acetate treated and non-treated samples were significant difference $(p<0.5)$ found during the storage period. At the end of $7^{\text {th }}$ day non-treated fish steaks over all acceptability was $6.5 \pm 0.57$ and treated fish steaks was $7.75 \pm 0.5$. On this basis we can say that non-treated fish steaks self-life not more than $7^{\text {th }}$ days and treated fish steaks self-life was more than $7^{\text {th }}$ days. The treated samples extended shelf life by antibacterial effect of this chemicals (Lee YL et al., 2002) ${ }^{[17]}$. (Khalid Ibrahim Sallam, 2007) ${ }^{[24]}$ reported that dipping of sliced salmon in $2.5 \%$ aqueous solution of $\mathrm{NaA}, \mathrm{NaL}$, or $\mathrm{NaC}$ significantly delayed the microbial growth and extended the shelf life of the product up to 15,12 , and 12 days, respectively. 
Table 5: Sensory panel scores of black pomfret steaks stored at $4{ }^{\circ} \mathrm{C}$

\begin{tabular}{|c|c|c|c|c|c|c|c|}
\hline \multirow{2}{*}{ Storage (days) Components } & Zero time & \multicolumn{2}{|c|}{ 3 days } & \multicolumn{2}{|c|}{ 5 days } & \multicolumn{2}{c|}{ 7 days } \\
\cline { 2 - 7 } & Raw & A1 & $\mathbf{A 2}$ & $\mathbf{A 1}$ & $\mathbf{A 2}$ & $\mathbf{A 1}$ & $\mathbf{A 2}$ \\
\hline Appearance & $9.25 \pm 0.5$ & $8.75 \pm 0.5$ & $9 \pm 0$ & $7.75 \pm 0.5$ & $8.25 \pm 0.5$ & $7.5 \pm 0.57$ & $8.25 \pm 0.5$ \\
\hline Colour & $9.5 \pm 0.57$ & $8.75 \pm 0.5$ & $9.25 \pm 0.5$ & $8.25 \pm 0.95$ & $8.75 \pm 0.5$ & $7 \pm 0.81$ & $7.5 \pm 0.57$ \\
\hline Odour & $9.5 \pm 0.57$ & $8.75 \pm 0.5$ & $9.25 \pm 0.5$ & $8 \pm 0.81$ & $8.5 \pm 0.57$ & $7.25 \pm 0.95$ & $7.75 \pm 0.5$ \\
\hline Overall Acceptability & $9.5 \pm 0.57$ & $8.75 \pm 0.5$ & $9.25 \pm 0.5$ & $7.75 \pm 0.5$ & $8.5 \pm 0.57$ & $6.5 \pm 0.57$ & $7.75 \pm 0.5$ \\
\hline
\end{tabular}

A1: Non-treated fish steak, A2: Fish steak Treated with $2.5 \%$ sodium acetate.

\section{Conclusion}

The results of the present study revealed that, chemical reactions, enzymatic as well as non-enzymatic reactions could proceed at low temperatures $\left(4^{\circ} \mathrm{C}\right)$ of storage. All of reactions have the potential for reducing the quality attributes of chilled fish, the rates of these deteriorations are increased as the time of chill storage progressed. Based on present study we can conclude that, sodium acetate dip treatment is for the maintenance of the functional properties of the seafood proteins which helps the preservation of the muscle integrity. Sodium acetate dip treatments were effective in inhibition of flavour, colour and lipid oxidation and thereby enhancing tenderness of seafood by restricting protein denaturation and reduces other deterioration of black pomfret quality during chill storage.

\section{References}

1. Association of Official Analytical Chemists. Official methods of analysis. $13^{\text {th }}$ Edition, AOAC, Washington, DC, 1980.

2. Banks H, II RN, Finne G. Shelf-life studies on carbon dioxide packaged finfish from the Gulf of Mexico. Journal of Food Science. 1980; 45(2):157-162.

3. Conway EJ. Micro diffusion analysis of volumetric error. Crosby, Lockwood and Son Ltd., London, 1950.

4. Cheret R, Delbarre-Ladrat C, Lamballerie-Anton M, Verrez-Bagnis V. Calpain and cathepsin activities in post mortem fish and meat muscles. Food Chemistry, 2007; 101:1474-1479. 10.1016/j. foodchem.2006.04.023

5. Connell JJ. Control of fish quality. Surrey, UK: fishing news books, 1975, 17.

6. Froese Rainer, Pauly Daniel eds. Parastromateus Niger in Fish Base. Version, 2013.

7. FAO. Review of the State of World Aquaculture. FAO Fisheries Circular No. 886, Rev. 1. Rome, Italy. Google Scholar, 1997.

8. Huss HH. Fresh Fish Quality and Quality Changes. FAO Fisheries Series, No. FAO, Rome, 1988, 29.

9. Jeyasekaran G, Ganesan P, Anandaraj R, Shakila RJ, Sukumar D. Quantitative and qualitative studies on the bacteriological quality of Indian white shrimp (Penaeus indicus) stored in dry ice. Food microbiology. 2006; 23(6):526-533.

10. Kamalakanth CK, Srinivasa Gopal TK. Development of ready-to-eat extruded fish-based noodles in semi-rigid containers" (Doctoral dissertation), 2016.

11. Kim CR, Hearnsberger JO, Vickery AP, White $\mathrm{CH}$, Marshal DL. Extending shelf life of refrigerated catfish fillets using sodium acetate and mono potassium phosphate. J Food. Protect. 1995; 58:644-647.

12. Kilinc B, Cakli S, Dincer T, Tolasa, S. Microbiological, chemical, sensory, color, and textural changes of rainbow trout fillets treated with sodium acetate, sodium lactate, sodium citrate, and stored at 4C. Journal of Aquatic Food Product Technology. 2009; 18(1-2):3-17.
13. Kim CR, Hearnsberger JO. Gram-negative bacteria inhibition by lactic acid culture and food preservatives on catfish fillets during refrigerated storage. Journal of Food Science. 1994; 59:513-516.

14. Li T, Li J, Hu W, Zhang X, Li X, Zhao J et al. Shelf- life extension of crucian carp (Carassius auratus) using natural preservatives during chilled storage. Food Chemistry. 2012; 135:140-145. 10.1016/j.foodchem.2012.04.115

15. Leon K, Mery D, Pedreschi F, Leon J. Color measurement in $\mathrm{L}^{*} \mathrm{a} * \mathrm{~b} *$ units from RGB digital images. Food Research International. 2006; 39(10):1084-1091. httpI://dx.doi.org/10.1016/j.foodres.2006.03.006.

16. Ludorff A, Meyer U. Fische und Fisherzeugnisse. Berlin and Hamburg, Germany: Paul Parey Verlag, 1973.

17. Lee YL, Cesario T, Owens J, Shanbrom E, Thrupp LD. Antibacterial activity of citrate and acetate. Nutrition. 2002; 18:665-666.

18. Manju S, Gopal TS, Jose L, Ravishankar CN, Kumar KA. Nucleotide degradation of sodium acetate and potassium sorbate dip treated and vacuum packed Black Pomfret (Parastromateus niger) and Pearlspot (Etroplus suratensis) during chill storage. Food chemistry. 2007; 102(3):699-706.

19. Mohan CO, Ravishankar CN, Gopal TS, Lalitha KV, Kumar KA. Effect of reduced oxygen atmosphere and sodium acetate treatment on the microbial quality changes of seer fish (Scomberomorus commerson) steaks stored in ice. Food microbiology. 2010; 27(4):526-534.

20. Puwastien P, Judprasong K, Kettwan E, Vasanachitt K, Nakngamanong Y, Bhattacharjee L et al. Proximate composition of raw and cooked Thai freshwater and marine fish. Journal of Food Composition and Analysis. 1999; 12(1):9-16.

21. Pomeranz Y, Meloan CE. Determination of moisture. In Food Analysis, Springer, Boston, MA, 1994, 575-601.

22. Pastoriza L, Sampedro G, Herrera JJ, Cabo ML. Influence of sodium chloride and modified atmosphere packaging on microbiological, chemical and sensorial properties in ice storage $\mathrm{f}$ slices of hake (Merluccius merluccius). Food Chem. 1998; 61:23-28.

23. Schubring R, Meyer C, Schlüter O, Boguslawski S, Knorr D. Impact of high pressure assisted thawing on the quality of fillets from various fish species. Innovative food science \& emerging technologies. 2003; 4(3):257267.

24. Sallam KI. Antimicrobial and antioxidant effects of sodium acetate, sodium lactate, and sodium citrate in refrigerated sliced salmon. Food control. 2007; 18(5):566-575.

25. Zhuang RY, Huang YW, Beuchat LR. Quality changes during refrigerated storage of packaged shrimp and catfish fillets treated with sodium acetate, sodium lactate or propyl gallate. J Food. Sci. 1996; 61:241-244. 